\title{
PROTOTYPE SISTEM INFORMASI MANAJEMEN KASIR KEDAI KOPI SIDIK BERBASIS ANDROID
}

\author{
Nurdiana Handayani ${ }^{1}$, Firdiansyah Firdaus ${ }^{2}$, Diki Ramadhan ${ }^{3}$ \\ Teknik Informatika, Fakultas Teknik Universitas Muhammadiyah Tangerang \\ Jl. Perintis Kemerdekaan 1/33 Cikokol Kota Tangerang \\ TLP. 55793251, 55772949, 55793802, 55736926 \\ E-mail: nurdiana.handayani@ft-umt.ac.id ${ }^{1}$, firdiansyah.firdaus@ft-umt.ac.id ${ }^{2}$,dramadhan40@gmail.com ${ }^{3}$
}

\begin{abstract}
ABSTRAKS
Kedai Kopi Sidik merupakan usaha yang mengedepankan konsep, teste dan pelayanan. Sistem pengelolaan data pemesanan, monitoring meja dan data produk menggunakan media kertas untuk proses pencatatannya, sehingga sering menemukan kendala-kendala seperti data yang redudansi, dan dokumen hilang atau data pesanan yang tidak sesuai. Sehingga Kedai Kopi Sidik membutuhkan sistem informasi manajemen kasir untuk mengatasi permasalahan yang terjadi. Sistem informasi manajemen kasir adalah suatu sistem yang dirancang dengan tujuan untuk memudahkan pemilik usaha dalam mengolah data produk, monitoring meja makan, dan data transaksi Kedai Kopi Sidik. Metode analisa pada prototype ini menggunakan user requirement specification dan aplikasi yang dibangun berbasis android dengan bahasa pemrograman php dan java. Sistem ini diharapkan dapat membantu proses yang berhubungan dengan pengelolaan sistem manajemen kasir.
\end{abstract}

Kata Kunci: Sistem Informasi, Manajemen Kasir, Prototype, Android

\begin{abstract}
Kedai Kopi Sidik is a business that puts forward concept, test and service. Order data management systems, table monitoring and product data use paper media for the recording process, so that they often encounter problems such as redundant data, missing documents or inappropriate order data. So Kedai Kopi Sidik needs a cashier management information system to solve the problems that occur. The cashier management information system is a system designed with the aim of making it easier for business owners to process product data, monitor dining tables, and transaction data at Sidik Coffee Shop. The analysis method on this prototype uses the user requirement specification and an application that is built based on Android with the PHP and Java programming languages. This system is expected to assist processes related to the management of the cashier management system.
\end{abstract}

Keywords: Information Systems, Cashier Management, Prototype, Android

\section{PENDAHULUAN}

Kemajuan teknologi memberikan dampak perubahan pada peradaban manusia, sehingga membawa tren baru dimana semua orang memanfaatkan teknologi seperti berkomunikasi massa untuk melakukan kegiatan sehari-hari. Teknologi terus berkembang dengan pesat dan tengah mengarah ke penggunaan mobile. Ditambah sekarang ini sudah memasuki era smartphone, sehingga banyak yang bisa dilakukan dalam satu genggaman saja. Hal ini juga terjadi disetiap bidang yang dapat dimanfaatkan para pelaku usaha baik dalam menarik pelanggan baru atau meningkatkan penjualan.

Kedai Kopi Sidik adalah salah satu usaha yang bergerak dibidang makanan dan minuman dan usaha yang mengedepankan Konsep, teste, dan pelayanan yang sudah berdiri hampir 2 tahun lamanya. Fasilitas Kedai Kopi Sidik masih menggunakan sistem informasi manajemen kasir konvensional baik dalam proses pemesanan, pencatatan dan pelaporan transaksi Kedai. Dengan kehadiran teknologi mobile memberikan dampak perubahan terhadap dunia usaha, karena banyak yang harus dirubah dalam mengikuti perkembangan teknologi mobile diantaranya fasilitas Kedai memerlukan upgrade dari Manajemen Kasir konvensional beralih ke aplikasi sistem informasi manajemen kasir berbasis android mobile.

Android merupakan "Open Mobile Platform" yang dikembangkan oleh Google, secara sederhana Android merupakan sebuah sistem operasi untuk handphone, seperti halnya Symbian atau Windows Phone. Android dikembangkan dari Sistem Operasi Linux, middleware, dan semua Aplikasinya dibuat dengan menggunakan Java. Perlengkapan penyediaan fitur dalam Android disertakan Standart Development Kid (SDK) dan pengembangan aplikasi dalam platform android disertakan Application Programming Interface (API) (Safaat, 2012).

Aplikasi Mobile adalah sebuah aplikasi yang memungkinkan Anda melakukan mobilitas dengan menggunakan perlengkapan seperti PDA, telepon seluler atau Handphone (Raharja, 2009).

Penerapan aplikasi mobile memberikan kemudahan bagi para pelaku bisnis, kecepatan dari 
akses dan sharing inforamasi lebih cepat sehingga dapat menghemat biaya usaha.

\section{Kajian Pustaka}

Penelitian terdahulu yang dilakukan oleh Gilang Pamungkas dan Herman Yuliansyah (2017) adalah sistem transaksi keuangan di kafe belum memanfaatkan kasir digital, hanya berupa mesin drawer. Sehingga terdapat batasan pada perhitungan transaksi. Tujuan dari penelitian menghasilkan aplikasi kasir tablet android untuk membantu proses transaksi penjualan dan dapat merekapitulasi laporan data transaksi di kafe. Selain itu, pada aplikasi ini ditambahkan fitur pencetakan kwitansi untuk pelanggan. Pengujian aplikasi android dilakukan dengan metode unit test dan menunjukkan sudah berjalan dengan lancar dan tidak ada method yang error, sehingga dapat dinyatakan lolos. Selain itu, pengujian black box test dapat disimpulkan bahwa aplikasi berjalan sesuai dengan yang telah dirancang. Penelitian lainnya yang pernah dilakukan oleh Muhammad Iqbal Merdeka Eka Putra, pada tahun 2012 tentang Aplikasi Penjualan berbasis Android mengenai perhitungan transaksi masih dilakukan menggunakan kalkulator sehingga memakan waktu apabila transaksi yang dilakukan banyak dan akan mengulangi perhitungan dari awal apabila terjadi kesalahan perhitungan. Penelitian lainnya yang pernah dilakukan oleh Laizim Suhendi (2015) yaitu system pelayanan pada rumah makan atau restoran yang dapat diolah oleh sebuah system aplikasi bukan hanya dalam hal mempermudah atau mempercepat pengolahan data manual menjadi akurat dan terstruktur, namun dapat dikembangkan menjadi sebuah system aplikasi pelayanan kepada konsumen. Tujuan dari system aplikasi pelayana rumah makan berbasis client server ditujuhkan untuk para karyawan dan pelaku bisnis dibidang kuliner agar dapat memberikan pelayanan yang optimal kepada para konsumen.

\subsection{Rumusan Masalah}

Berdasarkan uraian yang dijelaskan dalam prototype sistem informasi manajemen kasir yang mudah digunakan oleh Kedai Kopi Sidik dan aplikasi yang user friendly yaitu berbasis Android, antara lain:

1. Bagaimana merancang prototype sistem informasi manajemen kasir dengan menggunakan unified modelling language?

2. Bagaimana prototype sistem informasi manajemen kasir berbasis android memberikan kemudahan untuk pemilik usaha dalam mengelola sistem informasi manajemen kasir?

\subsection{Batasan Masalah}

Untuk membatasi permasalahan dalam penelitian ini agar lebih fokus pada prototype sistem informasi manajemen kasir, adalah:
1. Prototype sistem informasi manajemen kasir ini terintegrasi antara data kasir, koki dan pelayan.

2. Deployment aplikasi ini terdiri dari backend dan frontend. Untuk backend menggunakan framework Laravel dan frontend berbasis android

\section{METODE PENELITIAN}

Jenis penelitian yang diterapkan dalam pembuatan prototype aplikasi ini adalah jenis penelitian kualitatif dengan pendekatan studi kasus (study Case) pada Kedai Kopi Sidik yang dimana jenis penelitian ini bersifat menyeluruh, terperinci serta analisis yang mendalam dengan cara pengumpulan detail informasi menggunakan berbagai macam prosedur dan sumber data, guna mendapatkan hasil rancangan sistem dan user requirements spesification secara detail. user requirements specification adalah menggambarkan kebutuhan bisnis untuk apa yang dibutuhkan pengguna dari sistem. user requirements specification ditulis pada awal proses validasi, biasanya sebelum sistem dibuat. Mereka ditulis oleh pemilik sistem dan pengguna terakhir, dengan masukan dari jaminan kualitas.

Tahapan-tahapan dari user requirement specification mencakup sebagai berikut:

1. Pendahuluan

Pada tahapan ini menjelaskan pembahasan terkait ruang lingkup sistem, tujuan utama untuk proyek, dan masalah peraturan yang berlaku.

2. Persyaratan Program

Dalam pembahasan ini menjelaskan tentang fungsi dan alur kerja yang harus dapat dilakukan oleh sistem.

3. Persyaratan Data

Dalam tahapan ini menjelaskan terkait jenis informasi yang harus dapat diproses oleh suatu sistem.

4. Persyaratan Siklus Hidup

Persyaratan siklus hidup ini termasuk bagaimana sistem akan dipertahankan dan pengguna dilatih.

Merumuskan langkah yang digunakan dalam merancang prototype sistem informasi manajemen kasir dengan tahapan sebagai berikut:

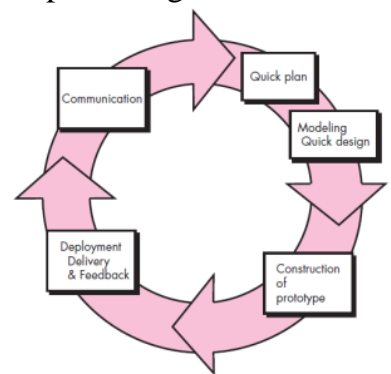

Sumber: Pressman(2010)

Gambar 2.1 Model Prototype 
Gambar 2.1 diatas menjelaskan 4 tahapan dalam perancangan sistem, sebagai berikut penjelasan pada masing-masing tahapan:

1. Communication

Pada tahapan ini melakukan wawancara serta diskusi terkait dengan sistem yang akan dirancang, dengan menggunakan tools User Requirements Specification untuk melakukan proses analisis terkait dari kebutuhan sistem tersebut.

\section{Quick Plan and Modelling Quick Design}

3. Pada tahapan Quick Plan yaitu membuat perencanaan cepat mengenai materi penelitian, jadwal penelitian dan tools yang digunakan untuk merancang aplikasi. Dan Pada tahapan Modelling Quick Design yaitu membuat pemodelan secara cepat, dimana pada tahap ini penulis menggunakan beberapa tools yang digunakan untuk merancang sebuah sistem ataupun user-interface, diantaranya:

a.Unified Modelling Language

b.Mysql

c. Figma

4. Construction of Prototype

Pada Tahapan ini akan membuat prototype berdasarkan hasil dari user requierments spesification yang dimana lebih difokuskan kepada tampilan user-interface system dengan menggunakan tools Figma

5. Deployment Delivery and Feedback

Setelah tahapan-tahapan sebelumnya sudah dilakukan dan disetujui oleh user kemudian proses selanjutnya adalah melakukan proses pembuatan aplikasi yang sesuai dengan tahapan-tahapan yang dilakukan. Proses pembuatan aplikasi meliputi backend dan frontend. Setelah aplikasi selesai kemudian diserahkan ke user untuk dilakukan testing serta evaluasi terhadap sistem tersebut.

\section{HASIL DAN PEMBAHASAN}

\subsection{Analisa Sistem Berjalan}

Berdasarkan metode pengumpulan data wawancara dan observasi yang dilakukan di Kedai Kopi Sidik, sistem yang diterapkan masih bersifat konvensional baik dalam proses penyajian informasi pemesanan, pengolahan transaksi pemesanan, datadata pengolahan data produk Kedai Kopi, dan proses laporan yang harus dibuat pada buku besar.

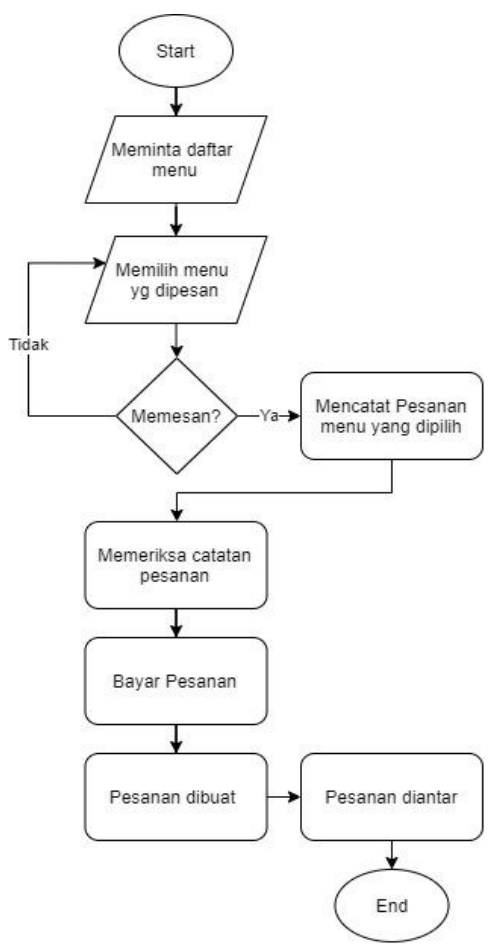

Gambar 3.1 Flowchart Sistem Berjalan

\subsection{Perancangan Unified Modelling Language}

Pemodelan yang digunakan untuk menvisualisasikan suatu sistem informasi manajemen kasir, diantaranya:

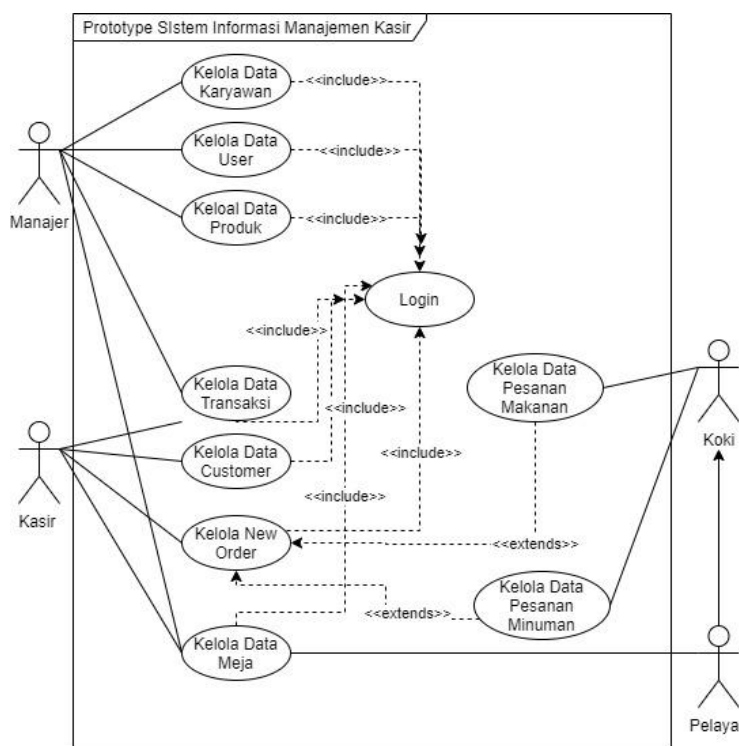

Gambar 3.2 Usecase Prototype Sistem Informasi Manajemen Kasir

\subsection{Perancangan User Interface}

Tampilan visual dalam sebuah aplikasi yang digunakan untuk menghubungkan antara sistem dengan user. 


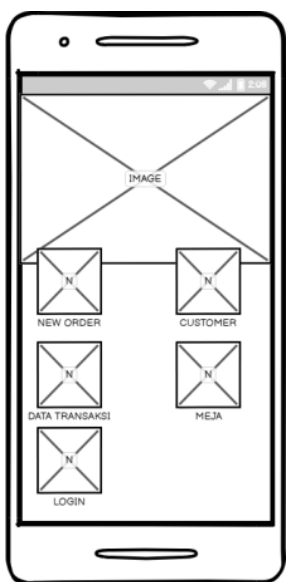

Gambar 3.3 User Interface Kasir Menu Mobile

Keterangan gambar 3.3 terdapat tampilan di aplikasi untuk akses Kasir, diantaranya:

a) Login, b) New Order, c) Customer, d) Data Transaksi, e) Meja

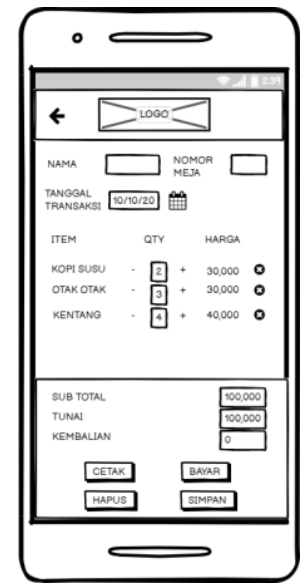

Gambar 3.4 User Interface Kasir Menu Pembayaran

Keterangan Gambar 3.4 menu pembayaran yaitu akan muncul pesanan makana dan minuman sesuai dengan pilihan customer yang diinput oleh kasir, dan kasih akan menginput nama customer dan jumlah yang uang yang dibayarkan.

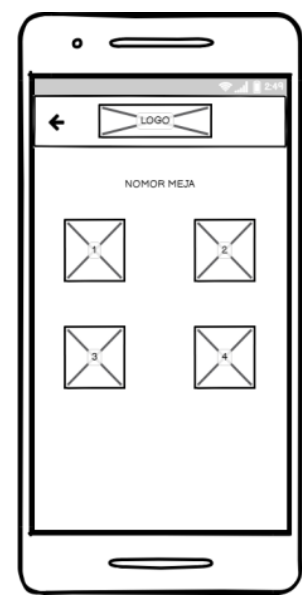

Gambar 3.5 User Interface Kasir Menu Meja
Gambar 3.5 diatas menjelaskan tampilan kasir dan pelayan untuk meja yang available untuk dapat ditempati oleh para customer yang datang memesan untuk makan di Kedai Kopi Sidiq.

\subsection{Pengujian Aplikasi}

Metode pengujian sistem dengan metode black box system yaitu melakukan pengujian tanpa harus mengetahui struktur internal kode dari sistem tesebut, seperti table dibawah ini:

Tabel 1. Pengujian Prototype Sistem Informasi Manajemen Kasir.

\begin{tabular}{|c|c|c|c|}
\hline No & $\begin{array}{l}\text { Testing } \\
\text { Action }\end{array}$ & Expected Output & $\begin{array}{l}\text { Testing } \\
\text { Output }\end{array}$ \\
\hline \multicolumn{4}{|c|}{ Scenario : Menu Utama } \\
\hline \multicolumn{4}{|c|}{ Actor } \\
\hline 1 & $\begin{array}{ll}\text { Klik } & \text { Menu } \\
\text { Karyawan } & \end{array}$ & $\begin{array}{l}\text { List layout data karyawan } \\
\text { tampil di layar }\end{array}$ & $\mathrm{OK}$ \\
\hline 2 & Klik Menu User & $\begin{array}{l}\text { List layout data user } \\
\text { tampil di layar }\end{array}$ & $\mathrm{OK}$ \\
\hline 3 & Klik Menu Produk & $\begin{array}{l}\text { List layout data produk } \\
\text { tampil di layar }\end{array}$ & $\mathrm{OK}$ \\
\hline 4 & $\begin{array}{ll}\text { Klik } & \text { Menu } \\
\text { Transaksi } & \end{array}$ & $\begin{array}{l}\text { List layout data transaksi } \\
\text { tampil di layar }\end{array}$ & $\mathrm{OK}$ \\
\hline 5 & Klik Menu Meja & $\begin{array}{l}\text { List layout data Meja } \\
\text { tampil di layar }\end{array}$ & $\mathrm{OK}$ \\
\hline \multicolumn{4}{|c|}{ Scenario : Create Data Karyawan } \\
\hline \multicolumn{4}{|c|}{ Actor : Manajer } \\
\hline 1 & $\begin{array}{l}\text { Klik button } \\
\text { Tambah }\end{array}$ & $\begin{array}{l}\text { Form create } \\
\text { karyawan tampil pada } \\
\text { layar }\end{array}$ & $\mathrm{OK}$ \\
\hline 2 & $\begin{array}{l}\text { a. Isi data yang } \\
\text { dibutuhkan } \\
\text { b. Klik Simpan }\end{array}$ & $\begin{array}{l}\text { Data tersimpan dan data } \\
\text { yang baru diinput } \\
\text { muncul di list data } \\
\text { karyawan }\end{array}$ & OK \\
\hline 3 & $\begin{array}{l}\text { a. Klik Button Edit } \\
\text { b. Lakukan edit } \\
\text { data yang } \\
\text { dibutuhkan }\end{array}$ & $\begin{array}{l}\text { Data yang akan diedit } \\
\text { tampil pada layar dan edit } \\
\text { data yang dibutuhkan }\end{array}$ & $\mathrm{OK}$ \\
\hline 4 & $\begin{array}{l}\text { a. Klik Button } \\
\text { Hapus } \\
\text { b. Lakukan hapus } \\
\text { data yang } \\
\text { dibutuhkan }\end{array}$ & $\begin{array}{l}\text { Pilih data yang akan } \\
\text { dihapus kemudian klik } \\
\text { tombol Hapus, maka data } \\
\text { akan terhapus }\end{array}$ & OK \\
\hline
\end{tabular}

\subsection{Antarmuka Sistem}

Hasil dari perancangan ini menjelaskan penggambaran dari sistem informasi manajemen kasir dan menghasilkan sebuah sistem aplikasi yang user friendly. 


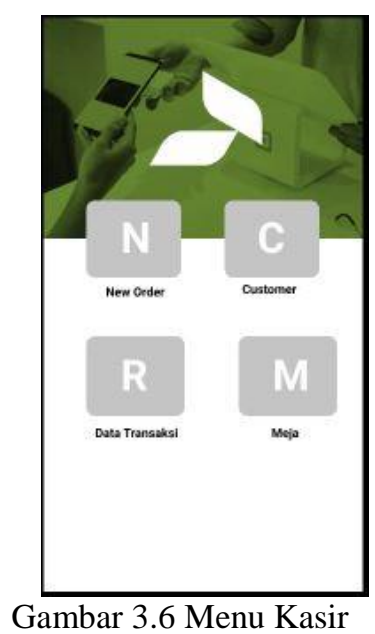

Keterangan gambar 3.6 diatas merupakan informasi menu-menu yang ada di Kasir yaitu New Order, Customer, Data Transaksi dan Meja.

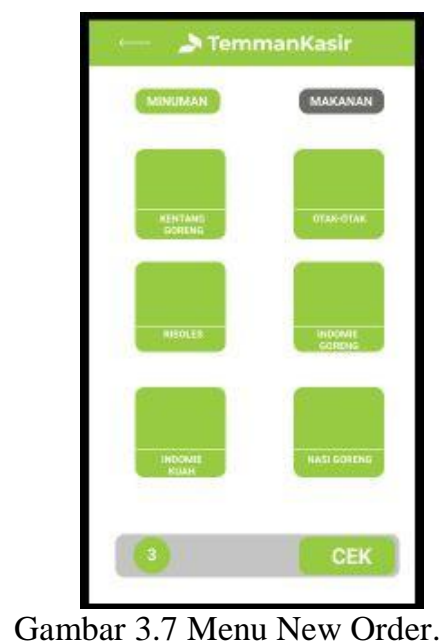

Keterangan Gambar 3.7 diatas mengenai menu pada new order, dimana kasir dapat memilih makanan atau minuman sesuai dengan pesanan customer

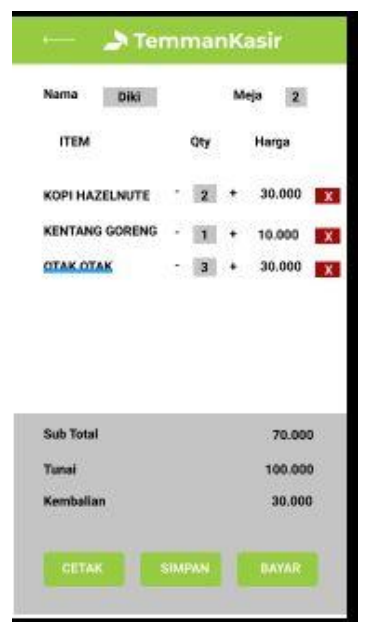

Gambar 3.8. Menu Pembayaran
Keterangan gambar 3.8 diatas mengenai informasi proses pembayaran customer terhadap pesanan makanan atau minuman yang tampil pada akses usernya Kasir.

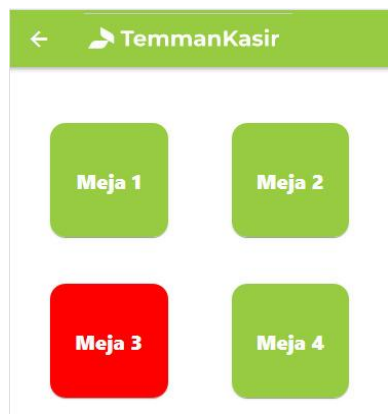

Gambar 3.9. Menu Meja

Keterangan gambar 3.9 diatas merupakan menu meja yang ada dimenu kasir dan pelayan, dimana mereka dapat mengetahui status meja apakah ada pengunjungnya atau tidak.

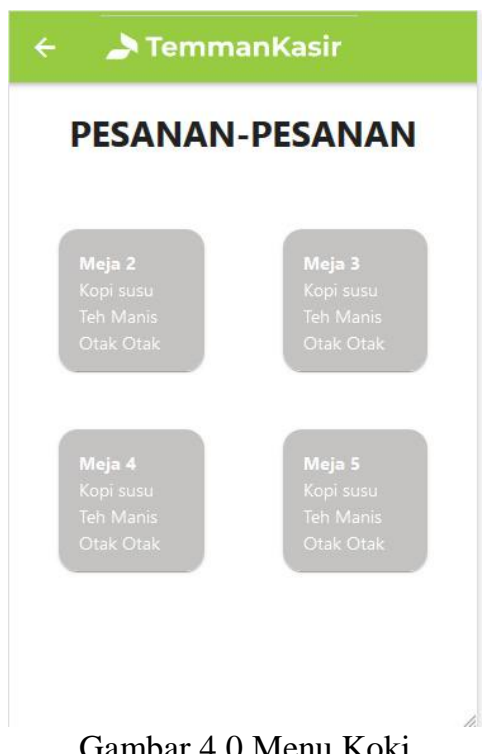

Keterangan gambar 4.0 diatas adalah menu koki berdasarkan pesanan-pesanan yang dipesan oleh customer untuk diolah menjadi makanan atau minuman.

\section{KESIMPULAN}

Dari hasil yang telah didapatkan pada prototype sistem informasi manajemen kasir ada beberapa kesimpulan sebagai berikut.

1. Sarana yang digunakan untuk merancang dan menvisualisasikan prototype sistem informasi manajemen kasir dengan menggunakan unified modelling language 
yang digambarkan dengan usecase diagram sebagai bahasa standar dalam penulisan blue print software.

2. Rancangan aplikasi ini terdiri dari backend dan frontend, dengan tujuan untuk memberikan kemudahan dalam sistem informasi manajemen kasir baik dari sisi pemilik usaha, kasir, koki dan pelayan. Dan aplikasi ini berbasis android dengan rancangan yang user friendly.

\section{PUSTAKA}

Destriana, Rachmat, Nurdiana Handayani, dkk. 2020. Perancangan Aplikasi Usaha Mikro Bank Sampah Syariah Menggunakan Aplikasi Android. P-ISSN: 2302-8734 E-ISSN: 25810006, Vol. 9 No. 2. Jurnal Teknik Universitas Muhammadiyah Tangerang.

M. I. M. E. Putra, "Aplikasi Ponsel Berbasis Android untuk Penjualan Pada Kios Eceran QMono Flower," STMIK AMIKOM Yogyakarta, 2012

Munawar, (2018). Analisis Perancangan Sistem Berorientasi Objek dengan UML. Bandung: Penerbit Informatika.

Muslihudin, Muhamad. 2016. "Analisis dan Perancangan Sistem Informasi Menggunakan Model Terstruktur dan UML".Yogyakarta: ANDI.

Raharja. 2009. (Online) (Lampiran. http://www.pribadiraharja.com/neli/SKIRPSI/La mpiran, diakses pada tanggal 25 Februari 2021)

Safaat H, Nazruddin. 2012. Android Pemrograman Aplikasi Mobile Smartphone dan Tablet PC Berbasis Android. Bandung: Informatika Bandung

Pamungkas, Gilang dan Herman Yuliansyah. 2017. Rancang Bangun Aplikasi Android Pos (Point Of Sale) Kafe Untuk Kasir Portable Dan Bluetooth Printer. P-ISSN : 2303-3142 E-ISSN : 25488570 Vol. 6, No. 1. Jurnal Sains dan Teknologi (Diakses Tanggal 25 Februari 2021)

Pressman, Roger S. (2010). Software Engineering A Practitioner's Approach $7^{\text {th }}$ edition. New York: McGraw-Hill. 